Plant Taxonomy, Geography and Floristics

https://doi.org/10.15407/ukrbotj78.05.319

RESEARCH ARTICLE

\title{
Lagenophora schmidiae (Asteraceae), a critically threatened new species from Aotearoa / New Zealand
}

\author{
Peter J. de LANGE ${ }^{1 *}$ (D), Jian $\mathrm{WANG}^{2}$ (D) \\ ${ }^{1}$ Unitec Institute of Technology, School of Environmental \& Animal Sciences, Private Bag 92025, Victoria Street West, Auckland
} 1142 , New Zealand

${ }^{2}$ Queensland Herbarium, Department of Environment and Science, Brisbane Botanic Gardens, Mt Coot-tha Road, Toowong, Queensland 4066, Australia

\begin{abstract}
Lagenophora schmidiae de Lange \& Jian Wang ter sp. nov. (Asteraceae) is described, illustrated and differentiated from L. montana Hook.f. The new species was first recorded from Aotearoa / New Zealand in 1974, when it was identified as L. montana. This relatively recent recognition reflects in part the fact that the new species is extremely uncommon, and has often been confused with the superficially similar L. barkeri Kirk, with which it often grows. A conservation status for L. schmidiae of 'Threatened / Nationally Critical' using the New Zealand Threat Classification System is proposed, as the new species is known only from small populations, many of which are threatened by alien weed invasion.
\end{abstract}

Keywords: Aotearoa / New Zealand flora, Asteraceae, Astereae, Lagenophora, Lagenophora barkeri, Lagenophora montana, Lagenophora schmidiae, new species, taxonomy

Article history. Submitted 23 August 2021. Revised 11 October 2021. Published 29 October 2021

Citation. de Lange P.J., Wang J. 2021. Lagenophora schmidiae (Asteraceae), a critically threatened new species from Aotearoa / New Zealand. Ukrainian Botanical Journal, 78(5): 319-326. https://doi.org/10.15407/ukrbotj78.05.319

*Corresponding author (e-mail:p.delange@unitec.ac.nz)

\section{Introduction}

Lagenophora Cass., nom. et orth. cons. (Asteraceae) is a genus of ca. 25 species (Wang, Bean, 2019), with nine species accepted for Aotearoa / New Zealand (Allan, 1961; de Lange, Rolfe, 2010; Breitwieser et al., 2012). Of the Aotearoa / New Zealand species, six are now considered endemic following the merger of Lagenophora lanata A.Cunn. into L. sublyrata (Cass.) A.R.Bean \& Jian Wang ter (Wang, Bean, 2019). Three species, Lagenophora montana Hook.f., L. stipitata (Labill.) Druce, and L. sublyrata, are considered indigenous being shared with Australia, and in the case of L. sublyrata, Australia, southern Asia (China, India, Sri Lanka), south-east Asia (Thailand), and Malesia (Java, New Guinea).

(C) 2021 P.J. de Lange, J. Wang. Published by the M.G. Kholodny Institute of Botany, NAS of Ukraine. This is an open access article under the terms of the Creative Commons Attribution License (http://creativecommons.org/licenses/by/4.0/), which permits use, distribution, and reproduction in any medium, provided the original work is properly cited
Of these three, one species, treated by Drury (1974) as Lagenifera [sic] montana, is an extremely uncommon plant that was first collected from the wild in Aotearoa / New Zealand in 1929 by Kenneth Willway Allison (1894-1976), a 'Forester', 'District Ranger' generic botanist and bryologist, who lived variously around Atiamuri, Rotorua, Waipoua in Te Ika a Maui / North Island and Dunedin, Te Wai Pounamu / South Island working for much of his life with the then New Zealand Forest Service (Macmillan, 1978).

Based on his herbarium annotations, Drury was initially uncertain of the identity of Allison's collections and other specimens collected by A.P. Druce for his Lagenifera [sic] treatment. However, on further consideration he eventually placed them in the Australian 
Lagenophora [as Lagenifera] montana. That species was described by Joseph Dalton Hooker (Hooker, 1847) from specimens collected on 11 January 1837, from Circular Head, Tasmania, by resident public servant (various posts), politician and botanist Ronald Gunn (1808-1881) (Burns, Skemp, 2021) (Lectotype: R. Gunn 832, K000890122; fide Cabrera, 1966). In their treatment of the Australian Lagenophora, Wang and Bean (2019) accepted a re-circumscribed L. montana from Tasmania and south-eastern Australia (South Australia, Victoria, Australian Capital Territory, and New South Wales), and they followed Drury (1974) and de Lange et al. (2010) in accepting that the species is also found in Aotearoa / New Zealand.

However, following the publication by Wang and Bean (2019) the senior author (P.J. de Lange) queried Jian Wang as to whether Aotearoa / New Zealand Lagenophora montana plants were correctly placed taxonomically, citing differences in their leaf shape, growth habit, and capitulum characters. Subsequent study of Aotearoa / New Zealand plants identified as Lagenophora montana confirmed that those plants were not conspecific with Australian L. montana but rather represented an undescribed, endemic species, which is here described as L. schmidiae.

\section{Materials and Methods}

This study is based on morphological examination of Lagenophora material from the following herbaria: AK, BRI, CANU, CANB, CHR, HO, MEL, and NSW. All measurements are based on dried material, except the dimensions of florets, which are based on material reconstituted with boiling water. Dimensions of measurements are inclusive, i.e. 1.0-1.7 is given as $1-1.7$.

\section{Taxonomy}

Lagenophora schmidiae de Lange \& Jian Wang ter sp. nov.

Type: AOTEAROA / NEW ZEALAND, Te Ika a Maui / North Island, South Auckland, near Atiamuri, 19 January 1929, K.W. Allison s.n. (holotype: MEL2067499 !; isotype CHR333534 [n.v.]).

Diagnosis: Lagenophora schmidiae resembles L. montana Hook.f., but differs in the long petiole (usually obvious and longer than lamina; petiole usually not obvious and shorter than lamina for L. montana), shorter ligule $(1.8-2.0 \times 0.3-0.4 \mathrm{~mm}$ c.f. $2.8-3.8 \times 0.4-$ $0.6 \mathrm{~mm}$ in L. montana) and longer cypsela beak $((0.5-)$ $0.6-1.1 \mathrm{~mm}$ long c.f. $0.2-0.4 \mathrm{~mm}$ in L. montana); also differs by the evenly distributed glands along both dorsal and ventral edges of the cypsela (rather than unevenly distributed glands along both dorsal and ventral edges of the cypsela or L. montana, i.e. fewer glands on ventral edge). Also similar to L. barkeri Kirk with which it often grows. Lagenophora barkeri differs from $L$. schmidiae by the coarsely serrate to crenate-serrate, rather than entire, sinuate-dentate to sparingly dentate, oblong rather than obovate, oblanceolate, or elliptical, leaf blades whose surfaces are conspicuously covered in bristly hairs, rather than seemingly glabrous (bearing sparse, appressed hairs).

Description [Fig. 2, A-E] Perennial rhizomatous herb. Roots fibrous and wiry, deeply descending, 0.5-1.0 $\mathrm{mm}$ diameter; rhizomes spreading through soil, up to 8 $\mathrm{cm}$ long. Stems erect and elongated with leaves loosely attached. Leaves 4-8 per stem, alternate along stem; petioles slender (with winged bases), 10-17 × 0.4-0.6 $\mathrm{mm}$; lamina obovate, oblanceolate or elliptical, $8-14 \times$ 4-6 $\mathrm{mm}$, base attenuate, apex obtuse often with midrib extending as a minute apiculus $0.1-0.2 \mathrm{~mm}$ long; leaf margins denticulate, occasionally entire or with 4-6 minute teeth, each tooth $0.2-0.4 \mathrm{~mm}$ long; adaxial surface bright green, abaxial surface lighter green, both surfaces glabrescent or finely, sparingly hairy, sericeous especially on the margins, hairs c. $0.1 \mathrm{~mm}$ long, translucent, patent; lateral veins obscure on dried material on both surfaces. Scapes terete, 1 per tuft, finely channelled, green with base sometimes tinged maroon, up to $140 \mathrm{~mm}$ long, 0.4-0.6 mm wide at anthesis, slightly longer at fruiting stage, glabrous in lower third to two-thirds otherwise finely hairy near or below capitulum; hairs c. $0.1 \mathrm{~mm}$ long, appressed, antrorse; bracts 1-2(-3), pale green, 1(-1.5) $\mathrm{mm}$ long, $0.2-0.4 \mathrm{~mm}$ wide, narrowly lanceolate, to deltoid, glabrous or occasionally furnished with a few minute, white, appressed, antrorse hairs. Capitula 2.5$3.5 \mathrm{~mm}$ long, 4-7 mm diameter; involucral bracts $31-$ $48(-58)$ in $4-5$ rows, the out $2(-3)$ rows initially widely and unevenly spaced, the uppermost row \pm forming an open, widely-spaced whorl, bracts deltoid, 1.0-1.3 $\times$ $0.25-0.4 \mathrm{~mm}$, glabrous, greenish, with stout midrib, erect or weakly spreading with upper third partially recurved, margins entire, upper third finely dentate, teeth greenish or maroon/purple, up to 6 either side, not paired, uneven and unequally spaced; the bracts of inner $2(-3)$ series, oblong, apex subacute to obtuse, with prominent 


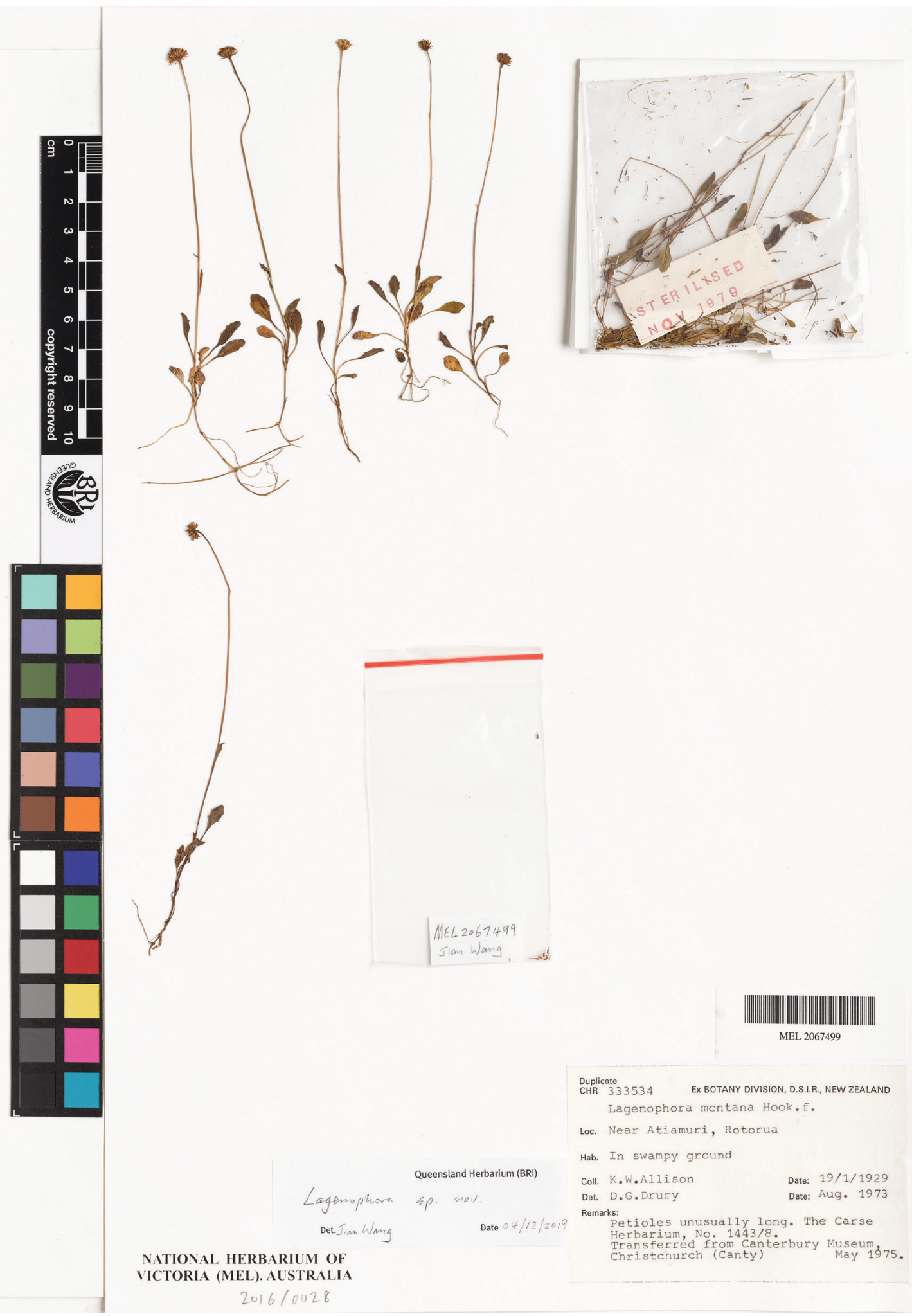

Fig. 1. Holotype of Lagenophora schmidiae de Lange \& Jian Wang ter (MEL2067499). Reproduced with permission from the Royal Botanic Gardens Victoria 


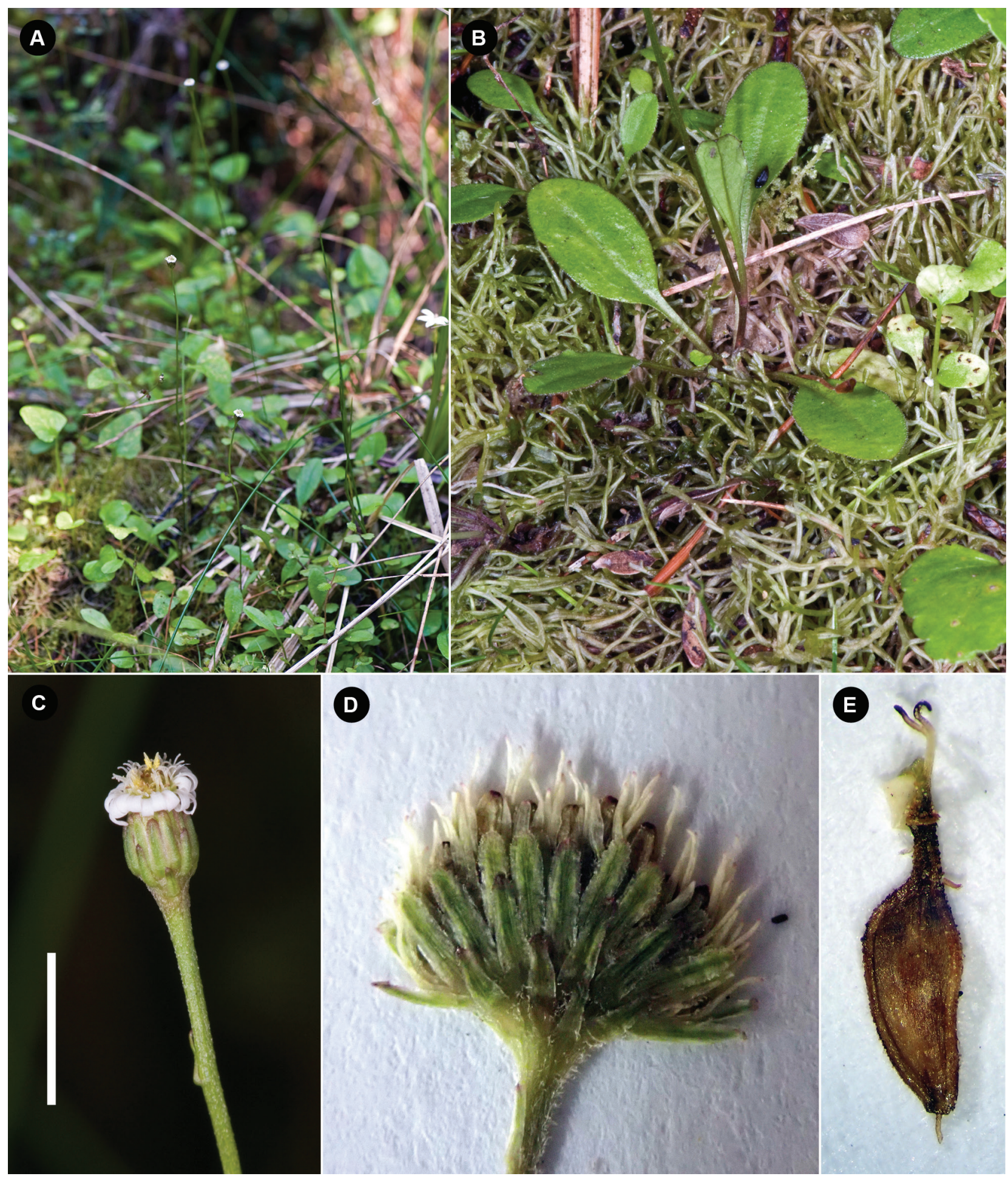

Fig. 2. Lagenophora schmidiae de Lange \& Jian Wang ter. A: habitat of plants growing in damp, shaded ground within frost flat, Hauhungaroa Range, near upper Kuratau River bridge; B: L. schmidiae rosette and foliage, Hauhungaroa Range, near upper Kuratau River bridge; C: Mature capitulum, Hauhungaroa Range, near upper Kuratau River bridge; D: Capitulum (pressed specimen, P.J. de Lange 5746, AK284561), Hauhungaroa Range, near upper Kuratau River bridge; E: Achene (pressed specimen, P.J. de Lange 5746, AK284561), Hauhungaroa Range, near upper Kuratau River bridge (images: A-C, J.R. Rolfe; D, E, P.J. de Lange) 
midrib, \pm glabrous except for margins; margins ciliate in distal third, cilia purple, with globular apices, 1.9-2.5 $\times$ $0.5-0.6 \mathrm{~mm}$. Receptacle convex, 0.8-1.5 mm diameter and $0.4-0.5 \mathrm{~mm}$ high. Ray florets $30-50$ in 2(-3) rows; tube $0.48-0.6 \times 0.2-0.25 \mathrm{~mm}, \pm$ glandular hairy; style branches initially white, maturing cream with maroontinged apices, $0.5-0.8 \mathrm{~mm}$ long; ligules $1.8-2.0 \times 0.3-0.4$ $\mathrm{mm}$ with $1(-3)$ longitudinal obscure veins, tightly coiled when mature (like most other species in the genus), white, often tinged mauve, apex obtuse, or notched. Disc florets 16-20(-22), corolla tubular, 1.0-1.5 mm long, cream, outer surface sparsely furnished with short glandular hairs, lobes 5, deltate, $0.4-0.5 \times 0.2-0.4 \mathrm{~mm}$, apices maroon or pink; stamens 5, 0.8-1.0 mm long (anthers c. $0.4 \mathrm{~mm}$ long, filament c. $0.3 \mathrm{~mm}$ long); style branches, white, apices tinged maroon, $0.4-0.5 \mathrm{~mm}$ long; ovary sterile, 0.8-1.4 $\mathrm{mm}$ long. Cypselas narrowly obovateelliptic to obovate, compressed, $1.7-1.9 \times 0.6-0.7 \mathrm{~mm}$ excluding beak; apex rounded to beak; base cuneate; margins with an obtuse rib; surface orange-brown, redbrown to purple-brown at maturity, with a light yellow margin, glabrous throughout; glands densely and evenly scattered along both dorsal and ventral margins, denser on beak and toward basal areas of both faces; beak (0.5-) 0.6-1.1 mm long, densely covered with glands, with a white annular collar at its apex, c. $0.2 \mathrm{~mm}$ diameter.

Representative specimens: Aotearoa / New Zealand. Te Ika a Maui / North Island. Kaimanawa Mountains, Lake Horotea, A.P. Druce s.n, Dec 1946, CHR116310; Maungaharuru Range, near Kopua, A.P. Druce s.n., Dec 1970, CHR216952; Puketitiri, Balls Clearing, A.P. Druce s.n., Mar 1972, CHR246135; Kaimanawa Mountains, Ngamatea, A.P. Druce s.n., Jan 1976, CHR279434; Central Volcanic Plateau Ecological Region, Taupo Ecological District, Hauhungaroa Range, near upper Kuratau River bridge, C.E. Ecroyd s.n., 18 Mar 1993, CHR486802; Cultivated at Taumarunui-Kuratau Road, near Kuratau River (Moerangi Settlement). Te Wai Pounamu, South Island. North west Nelson, Kahurangi National Park, Gouland Downs, A.P. Druce s.n., 1969, CHR197023; Canterbury, Cass, Lake Sarah, S.J. Wagstaff \& G. Sancho 7277, 6 Feb 2008, CHR605087 (note this is a mixed collection of Lagenophora schmidiae and probably L. barkeri); Southland, Te Anau, C.J. Burrows s.n., 1971, CANU14652. Ex. Cultivated. King Country Ecological Region, Taumarunui Ecological District, Hauhangaroa Range, near Kuratau River (Moerangi Settlement), P.J. de Lange 5746, 5 Nov 2003, AK284561.

Distribution and habitat: Endemic to New Zealand (Fig. 3) where it has been recorded [as L. montana] from

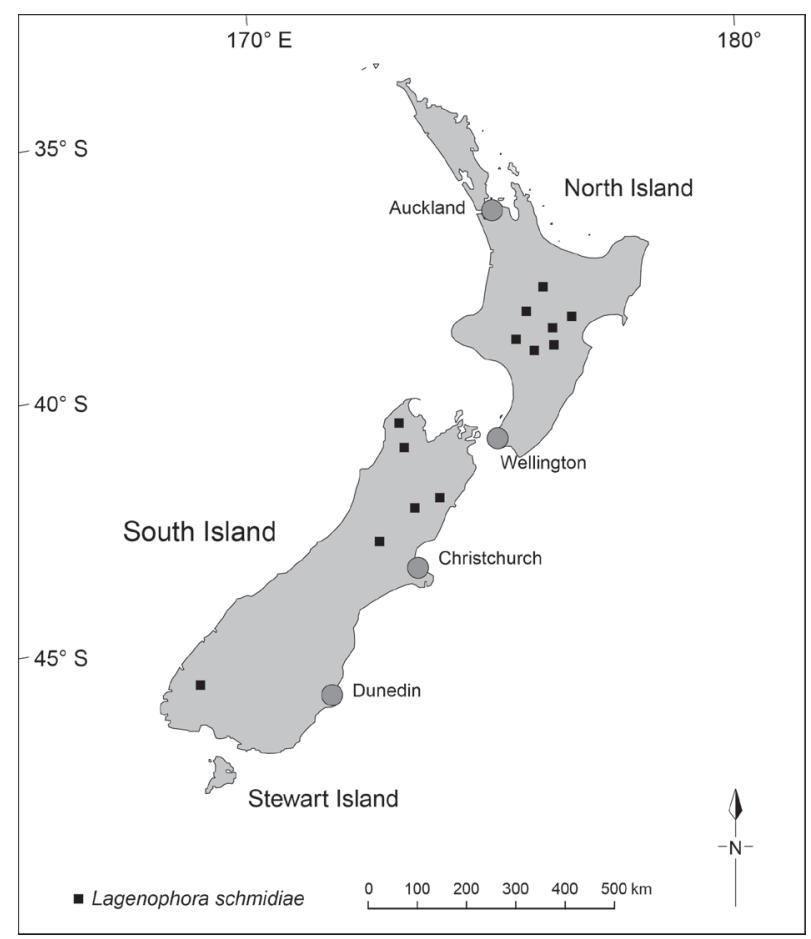

Fig. 3. Distribution of Lagenophora schmidiae (black circles), Aotearoa / New Zealand

lowland to alpine situations (from $260-920 \mathrm{~m}$ a.s.l.) from the central North Island, and from scattered stations in the north-western, eastern and south-western South Island (Drury, 1974; de Lange et al., 2010). Within that range Lagenophora schmidiae occupies a diverse range of wetland habitats including seeps, cushion bogs, swamps, lake and tarn margins, wet tussock grassland and stream banks, or damp, shaded rock shelves amongst mosses (de Lange et al., 2010; de Lange, 2021).

Phenology: Flowering (October-) November to February (-April). Fruits mainly from December to March, occasionally as late as June.

Affinities: Lagenophoraschmidiae is putatively closely related to the parapatric Australian endemic L. montana, from which it differs most obviously in the petiole which is usually longer than lamina (petiole is usually shorter than lamina for L. montana), smaller ligule $(1.8-2.0 \times$ $0.3-0.4 \mathrm{~mm}$ for L. schmidiae, $2.8-3.8 \times 0.4-0.6 \mathrm{~mm}$ for $L$. montana), longer cypsela beak $(0.6-1.1 \mathrm{~mm}$ for $L$. schmidiae, $0.2-0.4 \mathrm{~mm}$ for $L$. montana), and the narrower cypsela body $(0.6-0.7 \mathrm{~mm}$ for $L$. schmidiae, $0.8-1.0 \mathrm{~mm}$ for L. montana). The gland distribution of the cypsela is also different. Glands are densely and evenly scattered along both dorsal and ventral margins 
for L. schmidiae, while they are unevenly scattered along both dorsal (more glands) and ventral (significantly less glands) margins of both surfaces for L. montana .

Another species with a superficial similarity to Lagenophora schmidiae is L. barkeri (Drury, 1974), also an Aotearoa / New Zealand endemic which grows in similar habitats, sometimes sympatrically. Lagenophora barkeri differs from L. schmidiae by the leaf blades which are oblong rather than obovate, oblanceolate or elliptical, and whose surfaces are conspicuously covered in bristly hairs, rather than seemingly glabrous (bearing sparse, appressed hairs). The lamina margin of $L$. barkeri is coarsely serrate, to crenate-serrate rather than entire, sinuate-dentate to sparingly dentate as in L. schmidiae. Another key difference is the absence of glandular hairs on the adaxial margin of the achenes of L. barkeri. Drury (1974) noted that the ligules of the ray florets of Lagenophora (as Lagenifera) barkeri are white, whereas those of $L$. montana are pinkish, mauve or purple, colours we have not seen in plants referred to here as L. schmidiae whose ligules are white, but which are reported for L. montana s.s. in Australia (Walsh, Entwistle, 1999; Wang, Bean, 2019).

Conservation status: Lagenophora schmidiae, is, in the words of one of the most experienced current field botanists of Aotearoa / New Zealand, Shannel Courtney (pers. comm., 17 August 2021), "an enigmatic beast in my book - all of the possibles [sic] turn out to be L. barkeri. Quite concerning, as there appears to be so few records of this species nationally. Difficulty of identification may be some of the reason, but that doesn't account for the lack of collections generally, even if mis-identified".

This view is reflected in the current conservation status for the species which was as L. montana assessed by the New Zealand Indigenous Vascular Plant Threat Listing Panel as 'Threatened / Nationally Critical'. Those authors cited the threat classification pathway for that status as 'A3' [i.e., total area of occupancy estimated at $\leq$ 1 ha $\left(0.01 \mathrm{~km}^{2}\right)$ ], qualified 'DP' [Data Poor], 'SO' [Secure Overseas], Sp [Sparse] (de Lange et al., 2018) using the New Zealand Threat Classification System (NZTCS) (Townsend et al., 2008). This is the highest conservation status possible, reflecting that L. schmidiae is not only an extremely uncommon, biologically sparsely distributed plant with seemingly naturally small populations but also at serious risk of extinction. Currently, the species is represented in Aotearoa / New Zealand herbaria by 20 sheets, representing 11 localities, six from Te Ika a Maui / North Island locations and five from Te Wai Pounamu / South Island. There is also one reliable observation, made in the last 1980s but seemingly unsupported by herbarium evidence from the Upper Hope River (Buller Catchment), in the north-western portion of Te Wai Pounamu / South Island (S.P. Courtney, pers. comm., 17 August 2021). While, as of 18 August 2021, there has only been one record of this species reported on iNaturalist NZ (https:// inaturalist.nz/observations $/ 85017610$ ), that of a single plant observed from the Kutaroa portion of the extensive Raketepauma wetland, administered by Ngati Rangi located south of Waiouru in 2012 (N. Singers, pers. comm., 18 August 2021).

Of the herbarium records, all but three, made in 1985, 1993 and 2019, were collected before 1972 (3, Te Ika a Maui / North Island; 5, Te Wai Pounamu / South Island). Field surveys of many of these locations have failed to confirm extant populations, and, at the time of writing (18 August 2021), Lagenophora schmidiae is only reliably known from two extant locations, one near the Kuratau (Te Ika a Maui / North Island), and one from the Lake Sarah area (Te Wai Pounamu / South Island). In both locations the combined population area of occupancy is $<1 \mathrm{ha}$, and at these locations the species is threatened by weed invasion from a range of naturalised alien plants including species of Pilosella Vaill., exotic pasture grasses (Festuca L., Poa L.) and species of Juncus L. This updated data does not change the current threat status except that with the change in biostatus from an indigenous species (as Lagenophora montana) to a newly recognised endemic $L$. schmidiae, the qualifier 'SO' [Secure Overseas] is now wrong. Similarly, with the adjustment of the qualifiers used in the NZTCS, the qualifier 'DP' [Data Poor] needs adjustment to reflect the new qualifiers now in use for what has simply been 'DP' (Rolfe et al., 2019). Lagenophora schmidiae we believe qualifies for 'DPR' [Data Poor: Recognition] because the more common, and superficially, morphologically similar L. barkeri is frequently confused for $L$. schmidiae (see above); 'DPS' [Data Poor: Size], as there is no reliable information available on the numbers of plants in the wild; and finally, 'DPT' [Data Poor: Trend] due to the lack of trend data available for this species.

Etymology: This species is named for Ms Luzie Schmid (1999-) from Regensburg, Bavaria, Germany. Luzie is so honoured here for her assistance with field work on this species and other indigenous Aotearoa / New Zealand taxa, notably Leptospermum J.R.Forst. \& G.Forst. and, also, with the analysis of Lagenophora specimens used in this study and held in Aotearoa / New Zealand herbaria. 
Key to Lagenophora barkeri, L. montana and L. schmidiae

1. Petiole usually shorter than lamina, ligules mauve, yellow or rarely cream; glands unevenly distributed along both dorsal and ventral edges of the cypsela (fewer glands on ventral edge), Australian endemic L. montana

- Petiole equal to or longer than lamina, ligules white or sometimes cream; glands evenly distributed along both dorsal and ventral edges of the cypsela, New Zealand endemics .. 2

2. Leaves oblong, margins coarsely serrate to crenateserrate, lamina surfaces conspicuously bristly hairy; ligules more than $2.5 \mathrm{~mm}$ long L. barkeri

- Leaves obovate, oblanceolate, or elliptical, margins entire, sinuate-dentate to sparingly dentate, lamina surfaces seemingly glabrous (bearing sparse, appressed hairs); ligules up to $2 \mathrm{~mm}$ long, L. schmidiae

\section{Acknowledgements}

We are grateful for advice and comments received from Shannel Courtney, Jeremy Rolfe, and Nicholas Singers, regarding wild occurrences and the conservation status of Lagenophora schmidiae. We thank Pina Milne (MEL) for granting permission to make an image of the holotype for this paper. Luzie Schmid participated in field work and the analysis of Lagenophora specimens. As always, we appreciate the support of the Directors and Curators of AK, BRI, CANB, CANU, CHR, HO, MEL, and NSW for providing loan specimens, and especially Yumiko Baba and Ewen Cameron (AK) for providing a working space for the senior author and ongoing support and encouragement in these difficult days of the ongoing SARS-CoV-2 global pandemic. Jeremy Rolfe gave permission to use his images of Lagenophora schmidiae and prepared the plate (Fig. 1) and distribution map (Fig. 2). Useful comments of two anonymous reviewers are greatly appreciated.

\section{References}

Allan H.H. 1961. Flora of New Zealand, vol. 1. Wellington: P.D. Hasselberg, Government Printer, liv + $1083 \mathrm{pp}$.

Breitwieser I., Brownsey P.J., Garnock-Jones P.J., Perrie L.R., Wilton A.D. 2012. Phylum Tracheophyta - vascular plants, pp. 411-459. In: Gordon D.P. (Ed.) New Zealand inventory of biodiversity, vol. 3: Kingdoms Bacteria, Protozoa, Chromista, Plantae, Fungi. Christchurch: University of Canterbury Press, 616 pp.

Burns T.E., Skemp J.R. 2021. Gunn, Ronald Campbell (1808-1881). In: Australian Dictionary of Biography, National Centre of Biography, Australian National University. Available at: https://adb.anu.edu.au/biography/ gunn-ronald-campbell-2134/text2709, published first in hardcopy 1966 (Accessed 18 August 2021).

Cabrera A.L. 1966. The genus Lagenophora (Compositae). Blumea, 14: 285-308.

de Lange P., Heenan P.B., Norton D., Rolfe J., Sawyer J. 2010. Threatened plants of New Zealand. Christchurch: University of Canterbury Press, $471 \mathrm{pp}$.

de Lange P.J., Rolfe J.R., Barkla J.W., Courtney S.P., Champion P.D., Perrie L.R., Beadel S.M., Ford K.A., Breitwieser I., Schönberger I., Hindmarsh-Walls R., Heenan P.B., Ladley K. 2018. Conservation status of New Zealand indigenous vascular plants, 2017. New Zealand Threat Classification Series 22. Department of Conservation, Wellington, $82 \mathrm{p}$.

de Lange P.J. 2021. Lagenophora montana Fact Sheet (content continuously updated). New Zealand Plant Conservation Network. Available at: https://www.nzpcn. org.nz/flora/species/lagenophora-montana/ (Accessed 13 August 2021).

Drury D.G. 1974. A broadly based taxonomy of Lagenifera section Lagenifera and Solenogyne (CompositaeAstereae), with an account of their species in New Zealand. New Zealand Journal of Botany, 12(3): 365-395. http:// doi.org/10.1080/0028825X.1974.10428875

Hooker J.D. 1847. Florae Tasmaniae Spicilegium; or, Contributions towards a Flora of Van Diemen's Land. London Journal of Botany, 6: 106-125.

Macmillan B.H. 1978. Kenneth Willway Allison 1894-1976. New Zealand Journal of Botany, 16(1): 169-172. https:// doi.org/10.1080/0028825X.1978.10429673

Rolfe J.R., Makan T., Tait A. 2019. Supplement to the New Zealand Threat Classification System manual - New qualifiers and amendments to qualifier definitions. Available at: https://nztcs.org.nz/ (Accessed 18 August 2021).

Townsend A.J., de Lange P.J., Duffy C.A.J., Miskelly C.M., Molloy J., Norton D.A. 2008. New Zealand Threat Classification System Manual. Wellington: Department of Conservation, 35 pp. Available at: https://www.doc.govt. nz/Documents/science-and-technical/sap244.pdf

Walsh N.G., Entwistle T.J. 1999. Flora of Victoria, vol. 4: Dicotyledons (Olacaceae to Asteraceae). United Kingdom, Oxford: Butterworth-Heinemann, 1000 pp.

Wang J., Bean A.R. 2019. A taxonomic revision of Lagenophora Cass. (Asteraceae) in Australia. Austrobaileya, 10(3): 405-442. Available at: https://www.qld.gov. au/data/assets/pdf file/0022/109084/wang-beanaustrobaileya-v10s3-405-442.pdf

Recommended for publication by S.L. Mosyakin 
де Ланге П.Дж., Ван Цзянь. 2021. Lagenophora schmidiae (Asteraceae), критично загрожений новий вид 3 Аотеароа /Нової Зеландії. Украӥнський ботанічний журнал, 78(5): 319-326 [In English].

Технічний університет УніТек, Окленд 1142, Нова Зеландія: П.Дж. де Ланге. Гербарій Квінсленду, відділ навколишнього середовища та науки, Ботанічні сади Брісбена, гора Кут-та, Тувонг, Квінсленд 4066, Австралія: Цзянь Ван.

Реферат. Описано новий вид Lagenophora schmidiae de Lange \& Jian Wang ter sp. nov. (Asteraceae), наведено його зображення та відмінності від L. montana Hook.f. Цей новоописаний вид був уперше наведений з Аотеароа / Нової Зеландії у 1974 році, але під помилковою назвою Lagenophora montana. Таке досить пізнє визнання відокремленості цього виду частково пояснюється тим, що він $є$ надзвичайно рідкісним, а також часто помилково визначався як дещо подібний вид L. barkeri Kirk, з яким він часто зростає поряд. 3 використанням національної системи природоохоронної класифікації загроз (New Zealand Threat Classification System) для Lagenophora schmidiae запропоновано охоронний статус 'Threatened / Nationally Critical', оскільки цей новий вид відомий лише в малих популяціях, багато з яких знаходяться під загрозою внаслідок інвазій чужорідних видів.

Ключові слова: Asteraceae, Astereae, Lagenophora, Lagenophora barkeri, Lagenophora montana, Lagenophora schmidiae, новий вид, таксономія, флора Аотеароа / Нової Зеландії 